\title{
Service Innovation Theory and Its Latest Development: A Summary of Literature
}

\author{
Luhao Liu ${ }^{1, a^{*}}$ and Ling Liang ${ }^{2, b}$ \\ ${ }^{1}$ School of International Trade and Economics, Shandong University of Finance and Economics, \\ Jinan, 250014, China \\ ${ }^{2}$ Tourism and Event Management School, Shanghai University of International Business and \\ Economics, Shanghai, 201620, China \\ allhlsw@163.com, 'liang-ling@foxmail.com
}

Keywords: Service innovation; Product service system; Innovation of producer services

\begin{abstract}
With the constant development and deepening of service economy, this paper re-examines the current development status of service innovation in the theoretical perspective. After organizing previous literature, this paper puts forward 2 service innovation directions product service system and producer service, which are different from traditional service industry, and develops discussion from the perspective of their connotation, classification and application expansion. According to this paper, the shift from "product based" economy to "service based" economy, in addition to leading service, is emphasized by the current service innovation mode. It not only improves the current research on theories, but also means good instructions and experience for enterprises to innovate services.
\end{abstract}

\section{Connotation and Classification of Service Innovation}

Connotation of service innovation. In recent years, research scholars have been trying to define service innovation, for the purpose of distinguishing it from product innovation. In a broad sense, service innovation refers to all innovation behaviors or activities that are related to service or conducted for service, and their focus is "service product" and "service process". European service industry innovation system (1995) regards service innovation as brand-new or improved products or services, i.e. new applications of new technologies or existing technologies in original services; and also the activities for which enterprises use new ideas and new technologies to improve and reform product and service provision process and method, for the purpose of meeting diversified demands of customers, helping them realize value improvement and enabling enterprises to gain competitive edges (Vang \& Zellner, 2005)[1]. In a narrow sense, service innovation mainly refers to the innovation activities and behaviors of service enterprises; by laying emphasis on mode innovation of enterprises themselves, it includes the improvement of service process and service products, upgrading of service quality and efficiency or addition of new services, extension of existing services and improvement of service provision methods, etc. carried out by service enterprises (Berry et al, 2006)[2]. Generally speaking, service innovation refers to the activities for which enterprises use new ideas and new technologies to improve and reform product and service provision process and method, for the purpose of meeting diversified demands of customers, helping them realize value improvement and enabling them to gain competitive edges. According to the definition of service innovation, its objective is to secure customer's values and interests, realize customer's objective, and improve their own values finally.

Classification of service innovation. Former researches on service innovation are centralized on 2 levels: One is consumption service, where service is regarded as a kind of consumer goods. In this case, service can be pure consumer goods, and service activities and behaviors of traditional service industry can be discussed in terms of the service innovation in the narrow sense, for example, service innovation of tourism industry, retail industry, catering industry, etc. Since service objects of 
these industries are basically end consumers, most service innovations are based on marketing or product design. Moreover, service innovation can be regarded as the satisfaction of certain consumer needs instead of pure consumer goods, such as servitization of manufacturing industry, which refers to the process in which a manufacturer changes manufacturing-focused industry chain to service-focused industry chain in order to improve competence (Liu Bin et al, 2016)[3]. In this process, the manufacturer not only provides tangible products to consumers, but also satisfies certain functional demands of them based on tangible products. At present, the most direct interpretation of the servitization of manufacturing industry is product service system (Goedkoop et al, 1999)[4]. The other is producer services, which means using service as a production factor or complementary factor in production process instead of using it directly in consumption; service will not take effects directly. That is to say, producer services, which are targeting at producers other than consumers, are aimed to help producers realize better production and add values to product processes to generate effects indirectly; it can be considered non-final consumer services. The composition of service innovation according to this paper is as shown in Fig. 1; this paper describes product service system and producer services innovation mainly below.

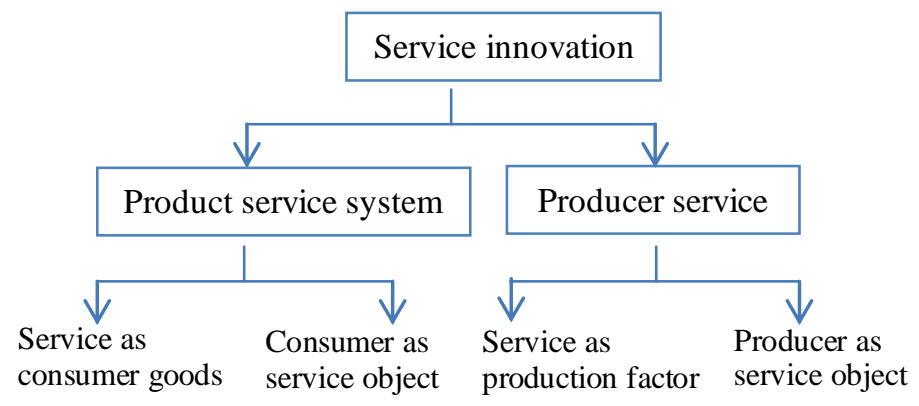

Figure. 1 Classification of Service Innovation

\section{Product Service System}

Generation of product service system. At present, different enterprises have gradually stepped into the era of narrow margin of profit from product, along with the acceleration of product upgrading and intensification of economic competition with the quick development of technical means. At the same time, Internet of Things and intelligent networking products change the sales-based commercial mode of enterprises thoroughly. At this moment, other industries, including manufacturing industry, in addition to service enterprises, need to take service innovation into consideration. The connotation of service innovation has also been changed. In the process where enterprises try to meet customer demands, the values in use that can be brought by products or services are emphasized, and customers can choose not to own or own fewer tangible products, in order to serve the functions of tangible products. That is to say, service innovation is not pure "intangible" services, but the integration of both "tangible" products and "intangible" services; the "diversity" of service innovation is not only shown by the improvement of service content and efficiency, as well as service process and method, but also the innovation of service-oriented commercial mode. Upholding the aforesaid philosophies, UNEP brought up the framework and concept of Product Service System (PPS) in late 1990s, providing a strategic choice for the realization of sustainable development in the perspective of the innovation of commercial mode.

Connotation of product service system. PSS provides total solutions needed by customers by strengthening the interaction relationship among different nodes of supply chain and the integration of tangible products and intangible services; its essence lies in the combination of functional products and value-added services (Goedkoop et al, 1999)[4]. Many early researches were limited to resource saving and ecological efficiency (Li Xiao, et al, 2011)[5], and thought that the main idea of PSS was to replace tangible products with intangible services, so as to reduce the impact of 
economic activities on substance consumption and environment. In the process where enterprises try to meet customer demands, PSS emphasizes the values in use that can be brought by products, and customers can choose not to own or own fewer tangible products, in order to realize the functions and tangible products, and thus saving resources. As the competition in product market intensifies and the production profitability of enterprises decreases recently, enterprises are forced to extend from production \& manufacturing to service provision-not only service prior to market such as transportation and delivery, but also post-market services including product maintenance, refitting and customer training (Aurich et al, 2006)[6], as well as product leasing consumption (Jui-Che Tu, et al, 2013)[7] and financing service (Velamuri, 2013)[8], with the aim to change the product-oriented commercial mode of enterprises fundamentally and improve their profitability by providing different kinds of services. In this case, PSS-based commercial mode has gradually become a strategic thought that enterprises have in order to gain competition edges (Chen Jing, Xie Jiaping, Wang Shuyun, 2013)[9]. It can be said that the appearance of PSS realizes the shift from "product based" economy to "service based" economy, and urges enterprises to pay more attention to the satisfaction of the personalized demands of customer other than large-scale batch production (Vasantha et al, 2012)[10]. What's more, enterprises become able to save resources and gain profits from the differential competition advantages based on service innovation. In the current international economic environment, it is a sustainable development strategy worthy of attention, for both enterprises and macro economy.

Classification of product service system. The essence of PSS lies in the combination of functional products and value-added services. Previously, the disagreement among scholars is mainly the properties of functional products: Some scholars thought that the ownership to PSS products should not be transferred to customers (Baines et al., 2007)[11], while others thought that it was covered by PSS whenever providers bundled services with products, even if the ownership was transferred to customer (Stevens et al., 2015)[12]. However, Extended Producer Responsibility (EPR) is promoted and PSS transforms its traditional single sales modes and extends to the "product and service" combined provision mode which is applicable to the whole life cycle; as a result, different opinions on product ownership are included in PSS. According to product ownership and service forms, PSS can be defined as 3 categories (Tukker, 2006)[13]: Product-Oriented Services, where services are added to products, such as training on using, maintenance and repair $\&$ recycling, Use-Oriented Services, where the ownership is generally reserved by providers, such as product pool plan, vehicle sharing plan and Result-Oriented Services, where functions and efficacies other than real products are provided; for example, a provider ensures the environmental temperature and humidity of a warehouse. Differences among these three models are as shown in Fig. 2. 


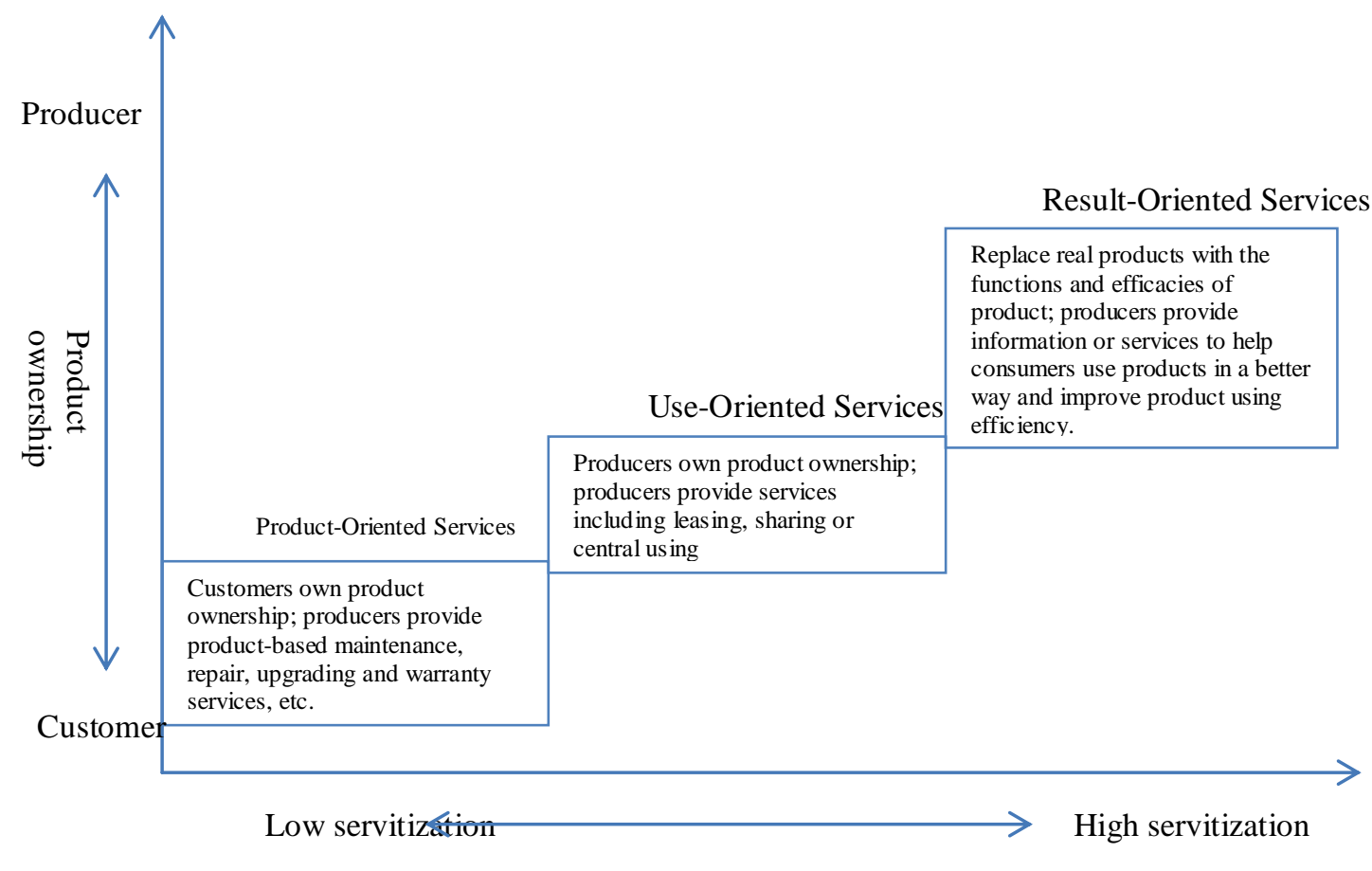

Degree of servitization

Figure. 2 Characteristics of and Differences among Different PSS Types

\section{Innovation of Producer Services}

Connotation of producer services. The concept of producer services is stemmed from the concept of "producer services" put forward by Greenfield (1996) [14]who thought that producer services were still certain services provided for producers other than consumers. This kind of producer services is provided by enterprises other than demanders. If the purpose of consumer services is to meet certain demand of consumer and let them obtain certain effects, then the purpose of producer service is to generate technologies or knowledge and generate effects indirectly by helping other enterprises. Producer services, which are only a kind of intermediate investment for demanding enterprises, are regarded as a production factor or certain arrangement that can help them realize better production. The difference between producer service and consumer service is that the former is not directly related to final consumers and cannot satisfy consumer demands; its main effect is to improve the efficiency of production links so as to help producers gain higher output.

Previous literature has basically specified the contents of producer services, and the commonly accepted opinion is that producer services include contents of 3 aspects: Information related software \& hardware, data processing, R \& D, market investigation and such; logistics, packaging and maintenance related to product and such; legal and financial services related to organizational support. As time passes by, however, both scientific technologies and social economy are different from the previous; therefore, detailed contents and applications of the above services have varied a lot. It can be found from the recent literature that the research on the content of producer services is more like the digging of the contents and application of certain producer service, such as supply chain finance, third party/fourth party logistics, application of Internet of Things, etc.

Innovation of producer services. Producer services can either be the "source" of innovation, or the "bridge" of innovation. The reason to call it a "bridge" is that producer services can be invested as intermediate products to drive demanders to realize innovation; during this process, producer services may inject factors such as technology, knowledge and resources to demanders, serving as the catalyst for enterprise innovation (Muller \& Zenker, 2001)[15]. The reason to call it a "source" is that producer service providers can promote the innovation behaviors of producer service enterprises through resource accumulation and interaction with demanders, and furthermore, launch 
new services to the market (Lee, 2003)[16] in possible ways through cooperation with other demanding enterprises. It can be said that the main effect of producer services is to promote the innovation of demanding enterprises when it acts as a "bridge", while to promote the innovation of itself when acting as a "source".

At present, most applications of and researches on producer services are based on manufacturing industry, and this is because producer services are given birth by manufacturing industry. Producer services separated vertically from manufacturing industry and developed professionally in order to change the versatile operation modes of enterprises and cope with the drawbacks shown by vertical integration. It is a new development trend for industrial organizations (Wu Fuxiang, 2005)[17]. According to the experience of developed countries, producer services play an important role in manufacturing industry, as it can improve the production efficiency of manufacturing industry and propels output values, and is also the important base to enhance the competence of manufacturing industry. According to previous researches, the relationship between producer services and manufacturing industry can be summarized as 4 levels, interaction theory, coherence theory, supplier push theory and demand following theory. Based on these 4 levels of literature, it can be considered that there is not simply a division of labor relation between producer services and manufacturing industry, but an interactively cooperative and promotive, and even derivative, development relation. In the complementary development process of producer services and manufacturing industry, constant cooperation, coordination and innovation are very necessary. The only way to form the co-evolution of producer service industry and manufacturing industry and realize industrial upgrade is to follow the economic characteristics of manufacturing industry and improving the effects of producer services through embedment mechanism (Liu Mingyu et al., 2010)[18].

Expansion of the applications of producer services. As agricultural circulation market develops constantly and the specialization level of product advances, the demand for producer services grows, and an increasing number of researches on the application of producer services in agriculture field are conducted. In the supply chain of agriculture, property of the innovation of producer services is the creative innovation of intermediate inputs, i.e. the innovation of enterprises based on their own resources and for the purpose of meeting the production demands of farmers. Innovation level includes: Improved variety before production, production and supply of agricultural supplies; technical guidance, information supply, epidemic prevention and insurance during production; agricultural product treatment, storage, processing, transportation and marketing after production; while financial services run through the whole chain (Zhuang Lijuan, et al., 2011)[19]. The reason why the innovation of producer services is needed is that many literatures mentioned the so-called "paradox of duality" problem shown by the current agricultural production: On the one hand, family farms and farmer cooperatives are based on individual farmers and farmer families; therefore, it is hard to promote the large-scale operation of agriculture, and the advantages of economy of scale cannot be shown, which is the drawback of the small-scale peasant mode of production. On the other hand, although large capital-leading farmers and enterprise-type production mode, such as "company + farmer" realize scale operation to certain degree, it cannot solve the micro incentive problem for capital supervised labor and employees. Producer services provide a train of thoughts to solve the above paradox: Firstly, promote the efficiency of smallholders by a certain form of producer services according to their production mode, so as to solve the difficulties they met in production process. For example, make up the asymmetric information and asymmetric supply problems between farmers and market with technical means, so as to promote the industrial development of agriculture (Zhou Shaodong, 2016)[20]; secondly, for capitalist agricultural production mode, capital accumulation and resource integration can be used to solve the difficulties met by smallholders during production, and "Internet + " mode can be used to solve supervision and management problems met by "enterprise + farmer" production mode through remote monitoring and intelligent management means (Zhou Shaodong, 2016)[20]. 
However, there is still a far way to go for "Internet +" to reach "Internet of Everything" in light of current technical level. Apparently, the agricultural production mode characterized by agricultural employment can still not solve the supervision and agent problems. Therefore, farmer-enterprise cooperation between smallholder production and capitalist production is the industrial mode that should be strongly recommended by agricultural industry. And the blending agent and catalyst in this process are the producer services and innovation facing agricultural supply chain.

\section{Conclusion}

Service innovation has gained the common attention from domestic and foreign scholars. As an important way to realize value growth and value co-creation, it needs to draw the attention and care from enterprises and various organizations. Based on many previous research results, this paper describes the innovation modes for product service system and producer services, emphasizes service-leading logics and also lays stress on the shift from "product based" economy to "service based" economy, providing a good reference for the following further and deeper research service management and innovation management.

\section{Acknowledgements}

Capital project: Shandong Province Natural Science Fund project "Research on the Service Innovation of Agricultural Social Enterprises under the Constraints of Dual Objectives" (ZR2017MG010); Shandong Province High School Humanities and social science research projects "New Thinking and Realization of Agricultural Supply-side Reform in Shandong Province-Based on Social Enterprise Perspective(J17RB140)

\section{References}

[1] Vang J, Zellner C. Introduction: innovation in services. Industry \& Innovation, 12(2005), No.2, p.147-152.

[2] Berry L L, Shankar V, Parish J T. Creating new markets through service innovation. MIT Sloan Management Review, 47(2006), No.2, p.56.

[3] Bin Liu, Qian Wei, Yue Lu, Kunfu Zhu, Servitization of Manufacturing and Value Chain Upgrading, Economic Research Journal, 12(2016), No.3, p.151-162. (In Chinese)

[4] Goedkoop M J, Van Halen C J G, Te Riele H. Product service systems, ecological and economic basics. Report for Dutch Ministries of environment (VROM) and economic affairs (EZ), 36(1999), No.1, p.1-122.

[5] Xiao Li, Zhenggang Liu, Xinjian Gu. Study on Enterprise Product Service System for Sustainable Development[J]. China Industrial Economics, 35(2011), No.2, p.110-119. (In Chinese)

[6] Aurich J C, Fuchs C, Wagenknecht C. Life cycle oriented design of technical Product-Service Systems. Journal of Cleaner Production, 14(2006), No.17, p.1480-1494.

[7] Jui-Che Tu,Yu-Chen Huang,Chuan-Ying Hsu and Yu-Wen Cheng. Mathematical Problems in Engineering,(2013), Article ID 710981.

[8] Velamuri V K, Bansemir B, Neyer A K, Möslein, K. M. Product service systems as a driver for business model innovation: lessons learned from the manufacturing industry. International Journal of Innovation Management, 17(2013), No.01, p.1340004.

[9] Jing Chen, Jiaping Xie, Shuyun Wang. A Review of the Studies on Product Service System Contracting. Journal of Yantai University, 2(2013), p.95-102. (In Chinese)

[10] Vasantha G V A, Roy R, Lelah A, Brissaud, D. A review of product-service systems design methodologies. Journal of Engineering Design, 23(2012). No.9, p.635-659.

[11]Baines $\mathrm{T}$ S, Lightfoot $\mathrm{H}$ W, Evans S, Neely, A., Greenough, R. State-of-the-art in 
product-service systems. Proceedings of the Institution of Mechanical Engineers, Part B: Journal of Engineering Manufacture,221(2007), No.10, p.1543-1552.

[12] Stevens R, Moray N, Bruneel J, Clarysse, B. Attention allocation to multiple goals: The case of for - profit social enterprises. Strategic Management Journal, 36(2015), No.7, p.1006-1016.

[13]Tukker A, Tischner U. Product-services as a research field: past, present and future. Reflections from a decade of research. Journal of cleaner production, 14(2006), No.17, p.1552-1556.

[14]Greenfield H I. Manpower and the Growth of Producer Services. (1966). ERIC Number: ED016143, p.163.

[15]Muller E, Zenker A. Business services as actors of knowledge transformation: the role of KIBS in regional and national innovation systems. Research policy, 30(2001), No.9, p.1501-1516.

[16]Lee K R. Innovation features and strategy of knowledge intensive service suppliers in Korea. The Knowledge management society of Korea, 4(2003), No.2, p.79-94.

[17]Fuxiang Wu. Studies on the Vertical Disintegration of Manufacturing in Economic Globalization. Finance \& Economics, 3(2005), p.113-120. (In Chinese)

[18]Mingyu Liu, Mingjie Rui. Kai Yao. Co-evolution between Producer Service Embedded in Value Chain and Industrial Upgrade of Manufacturing, 8(2010), p.66-75. (In Chinese)

[19]Lijuan Zhuang, Meiying He, Jie Zhang. Analysis on Demand Willingness and Influencing Factors of Producer Services in Agriculture. Chinese Rural Economy, 3(2011), p.70-78. (In Chinese)

[20]Shaodong Zhou, Agriculture Production Mode Reform Promoted by Internet plus, China Rural Survey, 6(2016), p.75-86. (In Chinese) 